\title{
Game-Play Language and Game-Play Intelligence - Wording, Planning, and Enacting Action Plans in Team Sports
}

\author{
By Paul Godbout * Jean-Francis Gréhaigne ${ }^{+}$
}

\begin{abstract}
The purpose of this paper is to discuss, in a socio-constructivist context, the development of students' game-play language and game-play intelligence through their wording, planning and enacting of action plans in team sports. At the beginning, the authors offer a brief recall of the basics of constructivism and social constructivism. They discuss students' perception of game-play reality, assimilation, accommodation and adaptation in relation with learning strategies in team sports. Then, they consider the development of a common game-play language and the evolution of students' exchanges over successive debate episodes interspersed with sequences of play. Beyond facilitating tactical learning, student construction of a common game-play language is seen as way to alleviate initial differences among students in terms of past sport experiences. Following theoretical considerations on the relationship between thinking and the development and the use of intelligence, the authors discuss the development of game-play intelligence and tactical thinking, considering the complementary use of convergent and divergent thinking. Finally, learners' awakening to metacognition is discussed in relation with the socially shared regulation of learning one may expect in a socio-constructivist approach to tactical learning in team sports.
\end{abstract}

Keywords: debate-of-ideas, divergent thinking, student/player exchanges, strategy thinking, tactical thinking

\section{Introduction}

In the teaching/learning of team sports, a characteristic common to several game-based approaches, in addition to being student-centered, is the use of exchanges between learners and between learners and their teacher as well (Kinnerk et al. 2018). Depending upon the particular model, modalities of exchanges may vary from questions and answers between the teacher/coach and the students/players, to more or less extensive debates among students/players. With regard to student verbalization, it has been suggested that student exchanges ought to rely more on divergent thinking, facilitating the pursuit of tactical learning (Harvey et al. 2016, Light and Georgakis 2005). This is especially so in a socio-constructivist approach where students are expected to collectively develop their tactical learning. The quality of students' exchanges relies, among other factors, on the extent of their conceptualization of game-play related constructs and on the extent and precision of game-play related terminology. While the

*Professor, Laval University, Canada.

${ }^{+}$Professor, University Burgundy Franche-Comté, France.

https://doi.org/10.30958/ajspo.8-1-2

doi=10.30958/ajspo.8-1-2 
former may be associated with game-play intelligence the latter relates to gameplay language, two constructs that will be discussed in this article.

The purpose of this article is to discuss, in a socio-constructivist context, the development of students' game-play language and game-play intelligence through their wording, planning and enacting of action plans in team sports. Following a brief recall of operational basics of constructivism and socio-constructivism, we will examine students' learning of game-play related concepts and language and discuss the development of tactical thinking and game-play intelligence. Finally, we will consider the repercussion of the regulation of developing game-play intelligence and tactical learning on learners' metacognitive awareness.

\section{The Socio-Constructivist Process in a Tactical-Learning Context}

\section{Basics of Constructivism and Social Constructivism}

Piagetian theory postulates that "human learning is constructed, that learners build new knowledge upon the foundation of previous learning" (Bada 2015, p. 66). The theory acknowledges three phases in the child's learning process, in relation with his/her perception of reality: assimilation, accommodation, and adaptation. Assimilation occurs when a learner receives new information or perceives a new situation and manages to fit that information or reality into an already existing mental scheme. Accommodation occurs when a learner transforms a pre-existing mental scheme in order to take into account dissonant perceptions of reality. Adaptation represents a state of balance between assimilation and accommodation, a phase when the reality perceived, whatever its variations, fits into the learner's mental scheme (Piaget 1962). Although not specifically pinpointed as part of the process, readers will note that whether going through assimilation, accommodation or adaptation, the learner first reacts to some type of perception of reality. Perception of reality is a starting point not to be overlooked in a deliberate and organized learning context.

Besides postulating that children construct their learning into mental schema, based on received information, Vygotsky's theory considers that they are also influenced by adults, their peers and their social environment (Yvon and Zinchenko 2011). In other words, the child's development is socially situated and constructed through interactions with others.

\section{Socio-Constructivist Perspective of Learning in Team Sports}

In physical and sport education, activities involving interacting participants offer a teaching/learning context particularly propitious to a socio-constructivist approach. This is even more so with team sports where collaboration with several teammates, while opposing several other players, is essential for success. Table 1 provides a general framework for students' social construction of knowledge with regard to team sports. 
Table 1. Social Construction of Knowledge in Team Sports: General Framework

\begin{tabular}{|c|c|}
\hline Learning phases & Related learning strategies \\
\hline $\begin{array}{l}\text { Perception of reality } \\
\text { Perception is the process through } \\
\text { which an individual takes into } \\
\text { account objects or characteristics } \\
\text { present in his/her environment. }\end{array}$ & $\begin{array}{l}\text { In a team-sport teaching/learning setup, one may } \\
\text { envision various information-retrieval strategies } \\
\text { such as (a) direct observation by the learner, (b) } \\
\text { reflection on action, (c) verbal interactions with } \\
\text { peers involved in game play, (d) verbal interactions } \\
\text { with teammate-observers, (e) verbal interactions } \\
\text { with the teacher. In coaching contexts, video- } \\
\text { feedback may also be considered. }\end{array}$ \\
\hline $\begin{array}{l}\text { Assimilation } \\
\text { Assimilation is the process } \\
\text { through which declarative or } \\
\text { procedural knowledge is } \\
\text { integrated by the learner who can } \\
\text { then apply it. }\end{array}$ & $\begin{array}{l}\text { Assimilation may occur with students' acquisition } \\
\text { of declarative knowledge relating, for instance, to } \\
\text { game-play terminology and play organization rules. } \\
\text { It may also occur when students' convergent } \\
\text { thinking is at work, for instance in problem-solving } \\
\text { situations when the task is to apply the proper } \\
\text { operations at the proper time (use of known } \\
\text { procedural knowledge). }\end{array}$ \\
\hline $\begin{array}{l}\text { Accommodation } \\
\text { Accommodation corresponds to } \\
\text { the adjustment made by } \\
\text { modifying one's knowledge or } \\
\text { procedural knowledge when it } \\
\text { proves to be inoperative in a new } \\
\text { situation. }\end{array}$ & $\begin{array}{l}\text { Accommodation, corresponding to the effective } \\
\text { construction of tactical knowledge, is likely to } \\
\text { occur in situations requiring divergent thinking on } \\
\text { the part of the learners. Student observation of } \\
\text { game play, exchanges and debates among students } \\
\text { in view of solving problems encountered during } \\
\text { prior game-play, followed by trials and } \\
\text { verifications during consecutive matches, will } \\
\text { solicit divergent thinking and facilitate } \\
\text { accommodation. }\end{array}$ \\
\hline $\begin{array}{l}\text { Adaptation } \\
\text { Adaptation occurs when } \\
\text { variations of a same or similar } \\
\text { nature in the perceived reality no } \\
\text { longer create a dissonance with } \\
\text { the learner's mental scheme. } \\
\text { Adaptation is associated with } \\
\text { stabilisation and generalisation. }\end{array}$ & $\begin{array}{l}\text { Adaptation will lead to a stabilization and } \\
\text { generalization of students' resources. There may be } \\
\text { three progressive facets to adaptation: } \\
\text { given successive trials of the same situation in the } \\
\text { same conditions, learners will keep being } \\
\text { successful; } \\
\text { confronted to varied similar play situations, learners } \\
\text { will display stable answers; } \\
\text { confronted to varied similar sport activities, learners } \\
\text { will display stable answers. }\end{array}$ \\
\hline
\end{tabular}

At the onset of the constructive process, learners perceive reality as they experience it. Strategies may however be implemented to provide additional information. Figure 1 illustrates a learning setup in which learners are engaged in a 4 vs 4 small-sided game. Associated with each team are two teammate-observers recording game-play occurrences based on pre-selected criteria. At times, the teacher (or coach) may also elect to observe both teams, one particular team or selected players depending upon his/her own agenda. Besides teammateobservation and teacher/coach observation, one may also consider that participant observation is at work. Indeed, as represented in each bubble associated with one player or another (players E2 and S3 have been selected for the sake of the 
illustration), each player in each team may be considered as involved in a participant-observation situation. Each one may directly observe the opponents (DOOps) or observe directly his/her teammates (DOTs, while reflecting on his/her own action during game play ( $\mathrm{R}$ in $\mathrm{A})$.

Figure 1. Observers Involved during Game Play

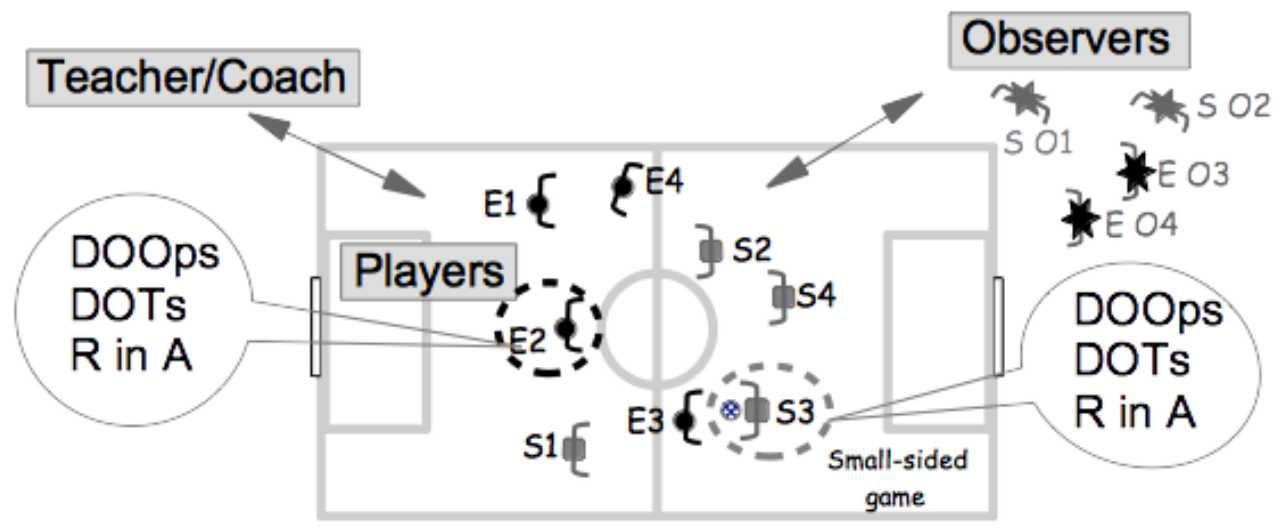

For its part, Figure 2 illustrates a learning setup in which, following a match, learners regroup on a team basis (players and observers) and proceed to exchange facts, reflections, and work hypotheses with regard to the last match and the one that will follow (summarized as debate in the Figure). Four different sources of information may be involved from the learner's point of view. We will as an example consider player E2 as a central figure of this illustration. The exchange includes the four players involved in the preceding match (E1 to E4), their two teammate-observers (EO3, EO4), and possibly the teacher/coach if he or she chooses to take part into the exchange (knowing that other debates may be going on, one of which involving team S (S1 to S4, plus SO1 and SO2 in Figure 1). The court or pitch illustrated in grey at the bottom of Figure 2 represents the reminiscence of the preceding match that is what all participants to the debate remember. One may think that as time goes by, souvenirs of the game-play sequence, vivid at first, will progressively fade in each person's mind. The grey representation of the playing area illustrates the reservoir of souvenirs at each participant's disposal. The bubble associated with player E2 identifies information received or given by the player: (a) the information may come from reflection on prior game play, or reflection on action (player reflection on action - PR o A); (b) the information may come from playing teammates as augmented feedback (TFB + ); (c) the player may provide augmented feedback to his playing teammates (PFB +). Finally, player E2 will receive information, or feedback, from his/her teammate-observers and, possibly, from the teacher. For its part, the bubble associated with teammate-observer EO4 identifies information processed by this student: (a) communication of observational results to teammates (ObRs); (b) observer's personal reflection on play actions witnessed (observer reflection on action - ObR o A) (c) communication of additional feedback on aspects of game play not included in pre-selected observational criteria $(\mathrm{FB}+)$.

In the two learning setups illustrated in Figures 1 and 2, exchanges between 
teammates and between students and the teacher are numerous. Exchanges with the teacher may concern feedbacks or at times take the form of questioning on the part of the teacher and answering on the part of students. Closed questions (recall or convergent) may be "associated with, for instance, the management of gameplay rules, the proper way to name game-related concepts, and so on. However, resorting to open-ended (divergent) questions is critical to elicit students' tactical thinking and the development of their tactical procedural knowledge" (Gréhaigne and Godbout 2020, p. 2). Similarly, students' planning of strategies during their debates will solicit their divergent thinking. Such learning setups demonstrate implicitly the fundamental importance of language for players and observers to function properly.

Figure 2. Information Sources in a Student-Exchange Setup with, as Background, the Reminiscence of Prior Game Play

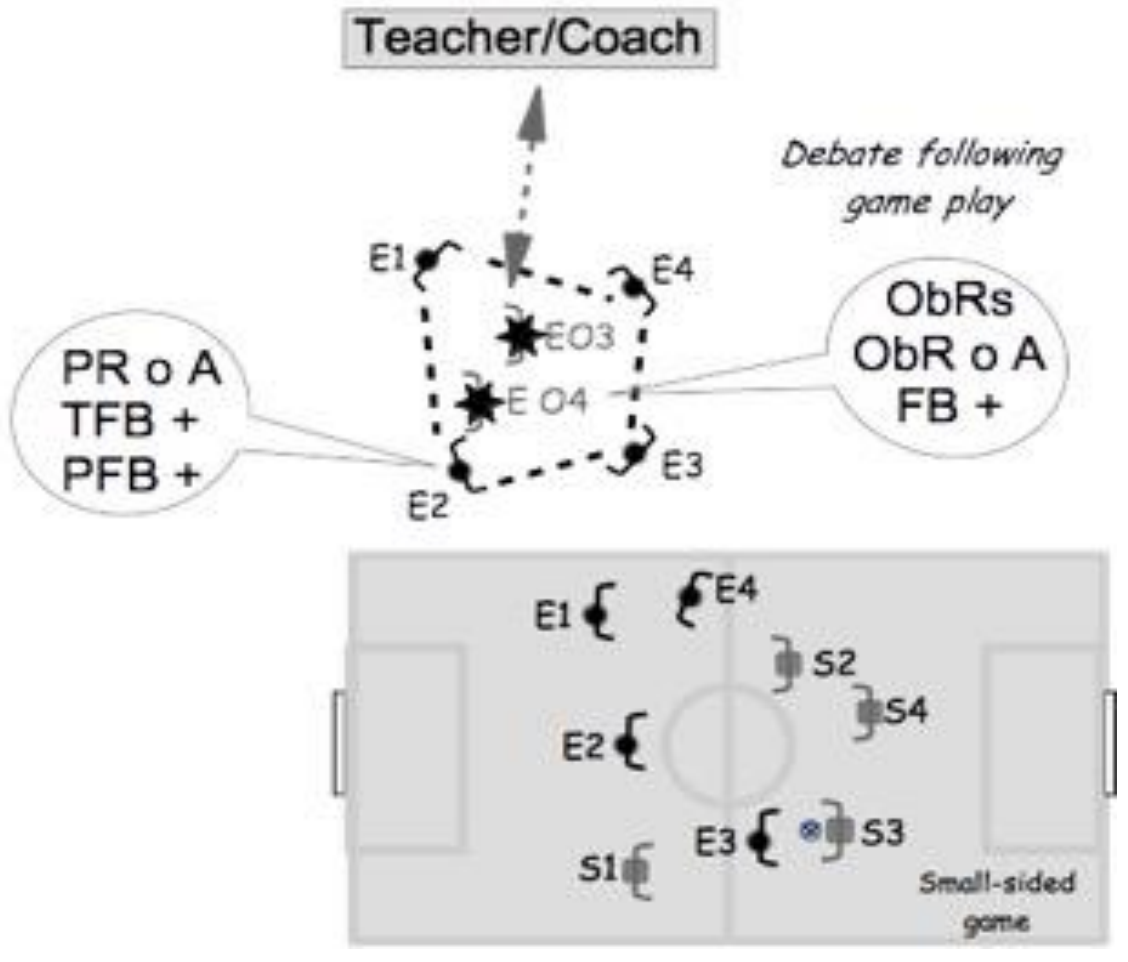

\section{Developing Game-Play Language: The Student/Player-Speaker}

Verbalization facilitates learners' reflection, understanding and observation by providing a database in view of exchanging with other players. One must differentiate the learner's construction of tactical knowledge and his/her acquisition of game-play language. Through past experiences, children have likely developed a basic language related to everyday games and leisure activities, summer camps, and so on, although there may be significant differences among students for different reasons [socio-economic, cultural, familial, and so on (Gréhaigne et al. 2017)]. They would be familiar with terms like throwing, catching, kicking, 
dodging and the like. At this point, most of that language would relate more to motor skills than to tactical skills. The latter are referred to in a semiotic code that learners must learn to share if they are to exchange among themselves and with their teacher or coach.

\section{Toward a Common Language}

Through past experience, players learned to use proper words to refer to one aspect of reality or another. Thus, learning team-sport related terminology fits their existing mental scheme and they can readily assimilate new words. Assimilating team-sport related terminology ought to be a situated process in the sense that there would be no use for a learner or a group of learners to develop a language of their own. The terminology already exists within the social environment and the community's culture. Within the boundaries of his/her pedagogical content knowledge, it is the teacher's responsibility to transmit this declarative knowledge through straightforward information, recall questioning or similar teaching strategies. In terms of learning, the process involved would be assimilation on the learners' part as alluded to before in Table 1. The development of a common game-play language will counter the initial difference among students mentioned above at the beginning of the present section. Readers will keep in mind that "terminology" refers to the words people agree to use to label things, movements, phenomena, occurrences, emotions, strategies, action rules, and so on. In the learning process, labelling something implies that the learner, unlike parrots, understands the meaning of the word, what that something is; the learner must grasp the underlying concept involved.

At first, in relation with observation, the teacher who masters pedagogical content knowledge (Chandler 1996) is well positioned to transmit to the class group the standard terms that express in words facts perceived by players and observers. At a higher level of abstraction, an explicit wording of a given individual or collective behavior or tactical answer conceived by learners may be associated with a play organization rule (POR) or an action rule (AR) (Gréhaigne and Godbout 1995) generally agreed upon by everyone. Through accommodation (see Table 1), learners construct, or reconstruct, these rules and then consciously use the word, notion or concept corresponding to the idea they developed. This way, resorting to verbalization in team sports makes it possible for learners to build a common team framework and recognize, on a conceptual level, action rules, play organization rules, notions of configuration of play, of effective-play space, of competency network, and so on (Gréhaigne and Godbout 1995, Gréhaigne and Godbout 2014).

The notion of language of the sport has been discussed by Caron and Pelchat (1974) with respect to Ice Hockey and by Mérand (1990) with respect to Basketball. According to Caron and Pelchat (1975, p. 52), "team-sport language seems to differ from one sport to the other. Such a conclusion implies that, from a pedagogical point of view, learning a team-sport language should mean learning the communication mode specific to that sport". Indeed, this may be true for highlevel sport, or non-invasive team sports (Ramos et al. 2020). Discussing the matter 
of a common language for ice hockey, Nadeau et al. (2014) submitted that beyond a general point of view where one finds a team-sports language (particularly with reference to similar sports, like invasion team-sports for instance) sharing common references, there remains the need for communicating about characteristics specific to a given sport based on specific play organization rules. For their part, referring to the principle of generalization of tactical learning across a variety of team sports, Gréhaigne et al. (1999) were of the opinion that students ought to develop a language that could be used with regard to the greatest possible number of activities. With these nuances in mind, we will, in this article, put forward the notion of game-play language in team sports.

That being said, during their debates or exchanges, learners resort back and forth to their everyday language, for general comments, and to game-play language for exchanges concerning subject- matter elements or tactical and strategic aspects of game-play.

\section{Evolution of Exchanges}

At first, words reflect the learners' need to communicate their interpretation of a situation experienced during game play. Through exchanges with peers, a reflective distancing sets in between the learner and his/her past actions (see Figure 2 ), generating a description and perceptions of game play. Thus, having contributed to the reflection on past action, language becomes a favored tool for putting forward game-play related concepts. Exchanges between learners denote the acquisition of a common language of play (Ramos et al. 2020) but also an evolution of the conception of game play, its components, its rules, and its tactical aspects.

It is no longer a matter of extracting game play from time for the sake of describing play actions or reflecting on them as illustrated in Figure 2. It becomes a matter of abstracting concepts or constructs from experienced or perceived occurrences and conceptualizing game play. Two complementary facets of conceptualization appear to be at play. First, through convergent thinking, learners may analyze, compare, categorize, differentiate, explain, synthesize. Then, stepping further in the construction process, they resort to divergent thinking to imagine, create, invent solutions and verify their appropriateness. As we will discuss later, this conceptualization process leads to tactical awareness and progressive understanding of game play (Gréhaigne and Godbout 1995, Godbout and Gréhaigne 2020b, Ramos et al. 2020).

Considering the qualitative aspect of learners' verbalization, it has been observed that debates or exchanges following game-play episodes modify interrelations between teammates, student-speakers becoming co-actors of the learning process. Indeed, exchanges may be shaped by one or the other of several contention levels. For instance, based on studies conducted by Nachon and Chang (2004) and by Chang (2009), one can submit the following five contention levels:

- assertion, which consists in describing and questioning experienced action plays in order to clarify their determinants and compare them to others; 
- judgment, which consists in prioritizing, qualifying, and debating observed facts depending upon their plausible issues;

- proposal, meaning the formulation of decisional alternatives, a gateway for possible actions;

- persuasion, which consists in trying to convince a teammate to collaborate in a collective action;

- conviction, which consists in stating ideas and/or principles considered as fundamentals with a high degree of certainty based on proofs.

Game-play language evolves as understanding and tactical awareness increase, a result of the accommodation process. Both understanding and tactical awareness also concur to the development of game-play intelligence.

\section{Understanding Game Play, Game-Play Intelligence and Tactical Thinking}

\section{Understanding Game Play}

Beyond a first level of understanding related to language and alluded to previously, the learners' challenge remains to understand the notions of POR and AR (Gréhaigne and Godbout 1995) and to construct them throughout the learning process while taking into account their motor and physical capacities. As a facilitator, the teacher will progressively put at their disposal a series of reference concepts (or constructs) related to game-play language such as a game plan, configurations of play, effective-play space, offensive and defensive matrices of play, respective competency network of each team involved, and so on (Gréhaigne and Godbout 2014). Understanding for succeeding indeed, but also succeeding for understanding. Understanding helps formulating action hypotheses; confirming the validity of the hypothesis, which offers a solution to problems encountered in the match, compels a critical analysis of reasons for this success and reinforces learners' understanding.

So far, we have mentioned on a few occasions the accommodation process learners go through while constructing knowledge. Accommodation refers to the learner's adjustment of schemas or cognitive frameworks as a result of new information or new experiences. It may also involve the development of additional schemas leading to conceptual networks. During game play, in a learner-centered approach, players are continuously faced with unexpected offensive or defensive problems they are challenged to solve instead of waiting for the teacher/coach to provide ready-made answers. Through exchanges with teammates, hypotheses, verifications and confirmation through game play, players understand that a given reality differs from what they thought and readjust their schemas accordingly; they learn through accommodation. They also learn through understanding, which explains Chandler's phrase "Understanding for learning" (1996, p. 51) or, as expressed by the National Research Council (NRC) (2000, p. 8), "...learning with understanding". 
Throughout debates/discussions among themselves and experimentation on the court, learners adjust their schemas to the point where the reality they experience is more and more in harmony with their schemas: they have adapted, as we have defined "adaptation" in Table 1. After stabilization, one may assume players use their tactical knowledge through convergent thinking; they are on a familiar ground. Following stabilization, a further step may be planned by the teacher in order to engage students into a generalization process. "With respect to generalization, teachers should encourage students to look for similarities between, for instance, invasion team sports in terms of tactics, action rules, matrices of play, prototypical configurations of play (PCPs), and so on". (Godbout and Gréhaigne 2020a, p. 12). As learners attempt to generalize their tactical knowledge across other team sports and experience different, although similar, realities, the accommodation process may resume temporarily, along with more divergent thinking until new adaptation sets in, and so on.

We submit that the progressive construction of understanding leads to the elaboration of a tactical knowledge base and conceptual networks likely to be used in convergent or divergent thinking processes. Convergent thinking will be at work when learners choose a tactical answer related to a familiar resolution context, whether nonlinear or not. Divergent thinking will set in when learners are looking for new answers in an unfamiliar context, possibly related to new constraints (e.g., new rules, new opponents). Such an assertion brings us to consider what we will call game-play intelligence, as well as tactical thinking.

\section{Game-Play Intelligence and Tactical Thinking}

\section{Theoretical Considerations}

Somehow, electing to discuss intelligence and thinking in a team-sport learning context is like inviting oneself to a buffet where supply largely exceeds demand. In such a case, we submit that the pragmatic solution is to make a choice, identify it and stand by it as suggested by Schlinger (2003, p. 21) who wrote "...perhaps behaviour scientists should instead take a more Darwinian view and look at the specific behaviours in their contexts that we label "intelligent," and then analyse them according to their function in those contexts".

The French Centre national de ressources textuelles et lexiques (CNRTL) [National center for lexical and textual resources] offers, among several others, the following operational definition of intelligence (2020a): in new circumstances for which instinct, learning or habit has no solution, [intelligence is] the aptitude for (a) grasping (comprehending) and organizing situational data, (b) putting together procedures to be used and the final aim, (c) choosing appropriate means or (d) discovering original solutions that will allow an adaptation to the requirements of the action. Such a definition fits particularly well the way we envision debates or exchanges among learners trying to find solutions to problems encountered during game play. Followed by a complement referring to an activity (game play, for example), the word intelligence is defined as an aptitude, a particular capacity, a gift for the activity concerned. As for thinking, the CNRTL (2020b) offers, among several others, the following definition: putting into operation an individual's 
intellectual capacities. From these definitions, we will retain that intelligence and thinking are intimately intermingled. We might consider intelligence as a capacity, an aptitude, more or less developed depending on the amount of knowledge, concepts and conceptual networks cumulated and understood by an individual. For its part, thinking, as related to a notion of mental process, would be the catalyst or putting into action of this capacity, a transmission belt working both ways, in and out.

The intermingling of these two constructs would come from the fact that thinking favors the development of intelligence (in a thinking $\rightarrow$ intelligence relationship, like a form of conceptualization or inductive thinking), which in turn allows a further elaborated expression of thinking (in an intelligence $\rightarrow$ thinking relationship, like a form of effector thinking or implementing thinking). Both would nurture each other as the awareness of a given reality develops.

In the context of this article on team-sports and games learning, going along with the above CNRTL suggestion, we will discuss game-play intelligence, considering its strategic and tactical dimensions, as we have previously submitted the notion of game-play language. While recognizing that thinking contributes to the development of both strategic and tactical intelligence, we will use the notion of tactical thinking since, from our point of view, in game-play situations and faced with time constraints, tactical thinking takes precedence over reflection in action and the implementation of new conceptual links. When appropriate, the latter will apply a-posteriori at times of reflection on action.

\section{Game-Play Intelligence and Tactical Thinking}

Concerning game-play intelligence, based on Stenberg's theory of intelligence (1985, 2005), we will use the notions of analytical intelligence and creative intelligence. Analytical intelligence is the capacity of analyzing, evaluating, judging, comparing, contrasting. It is thus related to convergent thinking, focused on problem solving based on known procedures. For its part, creative intelligence makes it possible for the learner to invent or imagine one or different solutions to a new problem; it relies on divergent thinking as we have alluded to previously. One may reasonably assume that when debating or exchanging during "tactical pauses" between matches, learners will make use of both types of intelligence whereas, most of the time, convergent thinking (as an expression of analytical intelligence) will prevail in game-play situations under the pressure of time constraints. Gréhaigne and Godbout (2020, p. 7) have recently written "During the match, faced with unexpected evolution of game play and under time constraints, students can no longer rely on thoughtful tactical reasoning. They need to resort to stored procedural tactical knowledge and be able to anticipate opponents' and or teammates' moves (Gréhaigne et al. 2001, Taylor 2016)".

From this point of view, we will not consider the notion of tactical creativity offered by Memmert $(2011$, p. 373) who wrote: "Tactical creativity is defined at the behavioral level as the unusualness, innovativeness, statistical rareness, or even uniqueness of solutions to a related sport situation in team-ball sports". According to this author, creativity is associated with the player's divergent-thinking ability used during game play, hence its rarity or uniqueness if one takes into account the 
various constraints related to game-play situations. Although it is true that it can be felt sometimes with expert players (the names of Gretzky and Lemieux come to mind in ice hockey and those of Cruyff and Platini in soccer), we do not think that the concept rightly applies in a learning environment involving beginners or novice players. We nonetheless agree with Büning et al. (2020) that the frequent use of divergent thinking combined with the exposure to various sport activities, a choice discussed in the Understanding Game play section of this article, may indeed concur to the development of creative potential and problem-solving capacity in young players.

As alluded to previously, under time constraints during a match game-play intelligence manifests itself through tactical thinking when unexpected situations occur with regard to the team's strategic plan. We have mentioned that the player's resort to divergent thinking is theoretically possible in an unusual moment of innovativeness; however, the temporal cost of such a choice may prove to be high. During game-play, the most appropriate approach is likely resorting to convergent thinking, the player reacting according to conceptual representations already available through game-play intelligence, a capacity referred to as "tactical intelligence" by Gréhaigne (2014b) and by Memmert (2011). Among such conceptual representations, one finds, for instance, offensive and defensive matrices of play, prototypical configurations of play, action rules, data regarding respective teams' competency networks, and effective-play spaces (Gréhaigne and Godbout 2014). Spotting the effective-play space may give a player a useful input at the tactical-thinking level, taking into account the player's perception of the configuration of play, his/her capacities, and what he/she knows of the teammates' and opponents' competency levels. All these conceptual landmarks develop through divergent thinking over successive lessons, debates with teammates, and the teacher's contributions, in contexts where learners have time enough at their disposal for integrating this knowledge and enriching their game-play intelligence. Then, when faced with the urgency of game play, the player's convergent tactical thinking takes over as he/she "tries to sustain at their minimum play-related constraints, uncertainties and randomness, while using to their maximum the capacities, potential and competencies at his/her disposal" (Gréhaigne 2014b, p. 32).

Through game-play intelligence, an "intelligent" player may anticipate teammates' or opponents' movements and even some evolution of configurations of play. In fact, one may consider two facets to anticipation of play. On the one hand, while preparing for a coming match, players may display strategic anticipation, planning possible reactions to plausible configurations of play, given their advance knowledge about opponents' competency network or preferred strategies (Mouchet 2014). On the other hand, as most often is the case, anticipation refers to tactical anticipation, that is, this "thinking leap" performed by a player sensing what will be a teammate's or an opponent's next move and reacting accordingly. Such a mental operation should not be mistaken for a dicey form of anticipation, be it an educated guess, a tactical choice discussed by Verscheure and Amans-Passaga (2014). Nadeau et al. (2020) had 18 Hockey players and 36 Football players describe each two critical incidents, referring to 
their last match: (a) one incident where they thought they had taken a good tactical decision during game play and (b) one incident where they thought they had taken a bad tactical decision during game play. Players were also asked to explain why they considered their decision as good or bad. Players answered the questionnaire on several occasions during their competition season. Among 289 reported positive decisions and 117 negative ones, players evoked offensive and defensive principles of game play. Moreover, on a few occasions, players described situations in which they had anticipated teammates' or opponents' actions. The authors concluded that these cases of anticipation "showed a better level of game-play understanding that went beyond the simple description of an experienced game-play situation" ( $\mathrm{p}$. 108; quotation translated by the authors).

With regard to tactical anticipation, research conducted with "expert" players in relation with anticipation show that (a) they make better use of information coming from their opponents' posture orientation, (b) predict more precisely the outcome of a given situation of play, and (c) remember or recognize rapidly and accurately structured patterns in situations of play (Stevenson 2013, Williams and Jackson 2019). Recognizing or reading game play rapidly implies thinking speed, a construct closely associated with the notion of anticipation according to Gréhaigne (2014a).

Players' game-play intelligence helps them (a) coordinate their actions with those of teammates, (b) interpret the evolution of configurations of play in relation with opponents' movements, that is (c) construct a capacity of anticipating and conceiving collective actions with their peers (Fernandez 2002). Concerning the matter of collective actions, Duarte and Frias (2011) have referred to the notion of collective intelligence. According to these authors, one may consider a team's performance as a collective intelligent behavior that is not centered on a particular player's consciousness but is rather distributed among all players. This reasoning, related to players' tactical behaviors within a team, connects with the notions of inter-player coordination (Memmert et al. 2017) or intra-team movement synchronization (Goes et al. 2020). Without assenting to the notion of collective intelligence as such, we concur with the idea that shared construction and stabilization of tactical knowledge, through socially shared regulation (Godbout and Gréhaigne 2020a), may lead to somewhat "empathic" tactical behaviors within a given team. To that effect, in relation with socio-economy- and gender-related differences in the classroom, the management of pedagogical learning content and learning setups is crucial (Poggi 2016). In order to reduce the gap between school and familial cultural environments, exposing students with difficulties to legitimate contents, or on the contrary adjusting the latter to the point of expelling all formative content, are not the solution. Teachers should rather offer their students sufficiently substantial-content situations likely to allow all students the construction and use of situated knowledge (Gréhaigne et al. 2017). 


\section{Learners' Awakening to Metacognition}

We have seen in Table 1 that the knowledge-construction process starts with the learner's perception of reality. Figures 1 and 2 illustrate information networks that may come into play during and after game play, helping learners to perceive that reality associated with game play. In the above section on Understanding Game Play, we have seen that learners involved in the accommodation process, when faced with new game-play related problems, exchange/debate with teammates, put forward action plans and test them in following sequences of play. Operationally, they are regulating their learning, mentally trying to accommodate.

"Teaching practices congruent with a metacognitive approach to learning include those that focus on sense-making, self-assessment, and reflection on what worked and what needs improving" (NRC 2000, p. 12). This statement by the National Research Council clearly suggests that a constructivist approach to learning can hardly ignore the benefits of learners' metacognitive awareness. This we believe applies not only to tactical learning but to the development of the underlying game-play intelligence as well. Ever since the term appeared in the literature in the 1970s (Dinsmore et al. 2008), and despite its complexity, metacognition continues to fascinate researchers (Alexander 2008), teacher educators (O'Hara et al. 2019), and practitioners (Gascoine et al. 2017). As alluded by Dinsmore 's et al. (2008) reference to the work of Vygotsky and Piaget, there is a definite connection between metacognition and constructivism, a connection which has been discussed on several occasions since the 1990s (e.g., Bay et al. 2012, Carr and Biddlecomb 1998, Fayol and Monteil 1994).

The classification of types of metacognitive knowledge has undergone parallel developments in three main research areas: computer science, psychology, and pedagogy. Although deliberations from these three areas often use a similar terminology, it is uncertain that constructs identified by the same terms are always equivalent from one domain to another and the notion of metacognition encompasses several distinct components within as metacognitive knowledge, metacognitive experiences and metacognitive skills or skillfulness (Gascoine et al. 2017). Given the plethora of metacognition-related constructs one finds in the literature (see, for instance, Bay et al. 2012, Gascoine et al. 2017, Langdon et al. 2019, McCormick et al. 2013, Quigley et al. 2018), there is definitely the risk for the teacher/coach, when drawing learners' attention on the metacognitive process, of reverting to a teacher/coach-centered rather than student-centered approach, the underlying miscomprehension being that students must master the concepts before they can proceed with learning. At this point, from a constructivist and socioconstructivist point of view, we submit that a suitable approach would be to draw learners' attention on the notion of metacognitive awareness, getting them to understand that there is a possibility for them to think about the way they learn to play tactically.

As stated by Godbout and Gréhaigne (2020b, p. 441), "becoming conscious, for instance, of the conditions that made [them] construct new tactical knowledge is not to be considered a black or white incidence, a Eureka moment, for most if not all students". O'Hara et al. (2019) have described a 4-stage metacognitive 
continuum, from a first no awareness/no action stage to an awareness/appropriate action/range of flexible strategies fourth one. Similarly, Perkins (1992) had suggested distinguishing four levels of metacognitive learners, from tacit, to aware, strategic, and reflective learners. While tacit learners do not think about any particular strategy for learning, aware learners begin to notice some of the thinking they do (like suggesting solutions, finding evidence), although this is not deliberate or planned. At the other half of the spectrum, strategic learners structure their thinking, making use of problem solving, combining and categorizing, and making choices. Finally, reflective learners not only plan their thinking but also reflect upon their actual learning, making connections between the results obtained and the way they proceeded to get there.

With regard to the teaching/learning of invasion team sports, Godbout and Gréhaigne (2020b), considering that ways of learning vary among students, have suggested keys to metacognitive awareness pertaining to three categories of student experience: (a) tasks-related experiences (e.g., observing game-play, debating); (b) team sport content-related experiences (e.g., configurations of play, teamcompetency networks); and (c) cognitive process-related experiences (e.g., analogical reasoning, use of advance organizers). These three categories illustrate the variety of cognitive experiences learners go through while developing teamsport tactical knowledge. Equipped with proper pedagogical content knowledge, the teacher/coach may indeed play the role of a facilitator (Goodyear and Dudley 2015), inciting students or players to reflect on what helps them regulate their learning without imposing his/her own metacognitive perspective.

Above, we have alluded to the notion of socially shared regulation of tactical learning. According to Godbout and Gréhaigne (2020a, p. 13), "In a team-sport teaching/learning context, ... although ever-present, self-regulation is intermingled with socially-shared regulation in the sense that each student's self-regulation activities are voluntarily mingled with those of his/her teammates to bring about a collective action plan". Going a step further, De Backer et al. (2018, p. 1301) have defined socially shared metacognitive regulation as "a joint engagement of multiple learners operating on each other's metacognitive contributions when regulating the group's cognition". This evidently represents a collective challenge but makes sense once each member of the group engages in a metacognitive process while sharing thoughts and reflection with his/her teammates.

\section{Conclusion}

In this article, we have discussed the development of game-play language and that of game-play intelligence with regard to a socio-constructivist approach to the learning of invasion team sports. We have also examined how tactical thinking is intermingled with game-play intelligence. Although these cognitive processes are constantly at work when individuals engage in a sport activity, discussing them on a theoretical basis remains a challenge. Engaging in the learning of a team sport with a socio-constructivist perspective implies not only a shared regulation of learning among players, each one helping the other, but also a socially shared one 
since all action plans agreed upon are based on collective decision-making. Considering the regulation of learning in a constructivist perspective brings about the matter of metacognition, a construct nested with self-regulation and selfregulated learning (Dinsmore et al. 2008). As we can find the expression "tactical awareness" in the literature (e.g., Deleplace 1979, Gréhaigne and Guillon 1991, Mitchell et al. 2013, Ramos et al. 2020, Rossi et al. 2007), so now can we regularly find "metacognitive awareness" as seen above. In this article, we have discussed the development of game-pay intelligence and we may eventually examine the question of "game-play-learning intelligence" in team sports that is an individual's capacity to monitor and regulate his/her tactical-learning processes with regard to team sports.

\section{References}

Alexander PA (2008) Why this and why now? Introduction to the special issue on metacognition, self-regulation, and self-regulated learning. Educational Psychology Review 20(4): 369-372.

Bada SO (2015) Constructivism learning theory: a paradigm for teaching and learning. IOSR Journal of Research \& Method in Education 5(6): 66-70.

Bay E, Bagceci B, Cetin B (2012) The effects of social constructivist approach on the learners' problem solving and metacognitive levels. Journal of Social Sciences 8(3): 343-349.

Büning C, Jürgens L, Lausberg H (2020) Divergent learning experiences in sports enhance cognitive executive functions and creativity in students. Physical Education and Sport Pedagogy (Aug).

Caron J, Pelchat C (1974) Le hockey, sport collectif : modèle empirique ou théorique (Ice hockey, a team sport: empirical or theoretical model). Mouvement 9(1): 33-46.

Caron J, Pelchat C (1975) Apprentissage des sports collectifs - Hockey/basket (Team sport learning - Ice hockey/basketball). Montreal, QC, Canada: Presses de l'Université du Québec.

Carr M, Biddlecomb B (1998) Metacognition in mathematics from a constructivist perspective. In DJ Hacker, J Dunlosky, AC Graesser (eds.), Metacognition in Educational Theory and Practice, 69-92. New York, USA: Routledge.

Centre national de ressources textuelles et lexiques - CNTRL (2020a) Lexicographie, intelligence (Lexicography, intelligence). CNTRL. Retrieved from:

https://www.cnrtl.fr/de finition/Intelligence/substantif. [Accessed 27 January 2021]

Centre national de ressources textuelles et lexiques - CNTRL (2020b) Lexicographie, pensée (Lexicography, thinking). CNRTL. Retrieved from: https://www.cnrtl.fr/ definition/Pensée/substantif. [Accessed 27 January 2021]

Chandler T (1996) Teaching games for understanding - Reflections and further questions. Journal of Physical Education, Recreation \& Dance 67(4): 49-51.

Chang C-W (2009) Langage, pensée et action: approche sémio-constructiviste des apprentissages du jeu en basket-ball chez l'élève de CM2 (5ième grade) (Language, thought and action: semio-constructivist approach to basketball game-play learning with $5^{\text {th }}$ grade pupils). Unpublished Doctoral Dissertation. Besançon, France: University of Franche-Comté.

De Backer L, Kollar I, Williams CA, Seufert T, Weinberger A, Melzner N et al. (2018) Assessing prerequisites and processes of self-, co- and shared regulation during 
collaborative learning. In J Kay, R Luckin R (eds.), Rethinking Learning in the Digital Age: Making the Learning Sciences Count. $13^{\text {th }}$ International Conference of the Learning Sciences (ICLS) 2018, Volume 3, 1296-1303. London, UK: International Society of the Learning Sciences.

Deleplace R (1979) Rugby de mouvement - Rugby total (Rugby in movement - Total rugby). Paris, France: Éducation Physique et Sport.

Dinsmore DL, Alexander PA, Loughlin SM (2008) Focusing the conceptual lens on metacognition, self-regulation, and self-regulated learning. Educational Psychology Review 20(4): 391-409.

Duarte R, Frias T (2011) Collective intelligence: an incursion into the tactical performance of football teams. In M Jemmi, A Palma, A Bianco (eds.), Proceedings of the First International Conference in Science and Football, 23-28. Palermo, Italy: Scuola dello Sport CONI Sicilia Publications.

Fayol M, J-M Monteil (1994) Note de synthèse - Stratégies d'apprentissage/apprentissage de stratégies (Synthesis annotation - Learning strategies/strategy learning). Revue Française de Pédagogie no. 106: 91-110

Fernandez A (2002) Rupture et prise d'avantage en sports collectifs, un modèle théorique (Rupture and taking advantage in team sports, a theoretical model). eJournal de la Recherche sur l'Intervention en Éducation Physique et Sportive no. 02: 03-17.

Gascoine L, Higgins S, Wall K (2017) The assessment of metacognition in children aged 4-16 years: a systematic review. Review of Education 5(1): 3-57.

Godbout P, Gréhaigne J-F (2020a) Regulation of tactical learning in team sports - The case of the Tactical-Decision Learning Model. Physical Education and Sport Pedagogy (Dec): 1-16.

Godbout P, Gréhaigne J-F (2020b) Revisiting the tactical-decision learning model. Quest 72(4): 430-447.

Goes FR, Brink MS, Elferink-Gemser MT, Kempe M, Lemmink KAPM (2020) The tactics of successful attacks in professional association football: large-scale spatiotemporal analysis of dynamic subgroups using position tracking data. Journal of Sports Sciences (Oct): 1-10.

Goodyear V, Dudley D (2015). "I'm a facilitator of learning!" Understanding what teachers and students do within student-centered physical education models. Quest 67(3): 274-289.

Gréhaigne J-F (2014a) Conclusion. In J-F Grégaigne (ed.), L'Intelligence Tactique. Des Perceptions aux Décisions Tactiques en Sports Collectifs, 315-318. Besançon, France: Presses de l'Université de Franche-Comté.

Gréhaigne J-F (2014b) L'intelligence tactique: quelques données (Tactical intelligence: a few comments). In J-F Grégaigne (ed.), L'intelligence tactique. Des Perceptions aux Décisions Tactiques en Sports Collectifs, 25-40. Besançon, France: Presses de l'Université de Franche-Comté.

Gréhaigne J-F, Guillon R (1991) Du bon usage des règles d'action (About the good use of action rules). Échanges et Controverses no. 4: 43-66.

Gréhaigne J-F, Godbout P (1995) Tactical knowledge in team sports from a constructivist and cognitivist perspective. Quest 47(4): 490-505.

Gréhaigne J-F, Billard M, Laroche J-Y (1999) L'enseignement des jeux sportifs collectifs à l'école. Conception, construction, évaluation (Teaching team sports at school. Conception, construction, assessment). Brussels, Belgium: De Boeck.

Gréhaigne J-F, Godbout P, Bouthier D (2001) The teaching and learning of decision making in team sports. Quest 53(1): 59-76.

Gréhaigne J-F, Godbout P (2014) Dynamic systems theory and team sport coaching. Quest 66(1): 96-116. 
Gréhaigne, J-F, Poggi M-P, Zerai Z (2017) L'enseignement et l'apprentissage des connaissances et des compétences motrices utiles en sport collectif (Teaching and learning of useful knowledge and motor competencies in team sports). e Journal de la Recherche sur l'Intervention en Éducation Physique et Sport no. 40: 163-184.

Gréhaigne J-F, Godbout P (2020) Debate of ideas and understanding with regard to tactical learning in team sports. Journal of Teaching in Physical Education (Jan): 110.

Harvey S, Cope E, Jones R (2016) Developing questioning in game-centered approaches. Journal of Physical Education, Recreation \& Dance 87(3): 28-35.

Kinnerk P, Harvey S, MacDonncha C, Lyons M (2018) A review of the game-based approaches to coaching literature in competitive team sport settings. Quest 70(4): 401-418.

Langdon J, Botnaru DT, Wittenberg M, Riggs AJ, Mutchler J, Syno M et al. (2019) Examining the effects of different teaching strategies on metacognition and academic performance. Advances in Physiology Education 43(3): 414-422.

Light R, Georgakis S (2005) Taking away the scary factor: female pre-service primary school teachers' responses to game sense pedagogy in physical education. In A Brew, C Asmar (eds.), Higher Education in a Changing World. Research and Development in Higher Education. Proceedings of the 2005 HERDSA Annual Conference, 260266. Milperra, NSW: Higher Education Research and Development Society of Australasia Inc.

McCormick C B, Dimmit C, Sullivan FR (2013) Metacognition, learning and instruction. In IB Weiner, WM Reynolds, GE Miller (eds.), Handbook of Psychology, Educational Psychology, 69-97. Volume 7, $2^{\text {nd }}$ Edition. Hoboken, New Jersey: John Wiley \& Sons.

Memmert D (2011) Sports and creativity. In MA Runco, SR Pritzker (eds.), Encyclopedia of Creativity, 373-378. Volume 2, $2^{\text {nd }}$ Edition. San Diego, CA: Academic Press.

Memmert D, Lemmink KAPM, Sampaio J (2017) Current approaches to tactical performance analyses in soccer using position data. Sport Medicine 47(1): 1-10.

Mérand R (Ed.) (1990) Basket-ball: lancer ou circuler (Basketball: throwing or moving?) Rencontres Pédagogiques no. 28: 9-38.

Mitchell SA, Oslin JL, Griffin LL (2013) Teaching sport concepts and skills: a tactical games approach for ages 7 to $18.3^{\text {rd }}$ Edition. Champaign, IL: Human Kinetics.

Mouchet A (2014) L'intelligence tactique in team sports (Tactical intelligence in team sports). In J-F Gréhaigne (ed.), L'Intelligence Tactique - Des Perceptions aux Décisions Tactiques en Sports Collectifs, 55-71. Besançon, France: Presses Universitaires de Franche-Comté.

Nachon M, Chang C-W (2004) Interactions verbales entre les élèves et projet d'action en basket-ball en classe de troisième (Verbal interactions between students and action project in basketball in high schools). eJournal de la Recherche sur l'Intervention en Éducation Physique et Sport no. 5: 15-36.

Nadeau L, Georget S, Fortier K, Godbout P (2014) Savoirs collectifs, intelligence tactique et hockey sur glace (Collective knowledge, tactical intelligence and ice hockey). In JF Gréhaigne J-F (ed.), L'Intelligence Tactique - Des Perceptions aux Décisions Tactiques en Sports Collectifs, 117-154. Besançon, France: Presses Universitaires de Franche-Comté.

Nadeau L, Martel D, Poulin-Beaulieu I, Couture-Légaré J (2020) L'utilisation de la technique des incidents critiques pour favoriser la réflexion de joueurs en sports collectifs (The use of critical incidents to enhance players' reflection on action in team sports). eJournal de la Recherche sur l'Intervention en Éducation Physique et Sport Special no. 3, 93-113. 
National Research Council - NRC (2000) How people learn: brain, mind, experience, and school: expanded edition. Washington, DC: The National Academies Press.

O'Hara S, Pritchard R, Pitta D (2019) Teaching with and for metacognition in disciplinary discussions. In N Feza (ed.), Metacognition in Learning. Chapter 4.

Perkins D (1992) Smart schools: better thinking and learning for every child. New York, USA: Free Press.

Piaget J (1962) La Psychologie de l'intelligence (Psychology of intelligence). Paris, France: Colin.

Poggi M-P (2016) Handball scolaire pour les filles en EPS. Quels risques d'inégalités (School European Handball for girls. Which risks of inequities)? In J-F Gréhaigne (ed.), Les Objets de la Technique. De la Compétence Motrice à la Tactique Individuelle, 271-286. Besançon, France: Presses Universitaires de Franche-Comté.

Quigley A, Muijs D, Stringer E (2018) Metacognition and self-regulated learning. Guidance report. London, UK: Education Endowment Foundation.

Ramos A, Coutinho P, Davids K, Mesquita I (2020) Developing players' tactical knowledge using combined constraints-led and step-game approaches - A longitudinal action-research study. Research Quarterly for Exercise and Sport (Jul).

Rossi T, Fry JM, McNeill M, Tan CWK (2007) The Games Concept Approach (GCA) as a mandated practice: Views of Singaporean teachers. Sport, Education and Society 12(1): 93-111.

Schlinger HD (2003) The myth of intelligence. The Psychologist Record 53(1): 15-32.

Sternberg RJ (1985) Beyond IQ: a triarchic theory of human intelligence. Cambridge: Cambridge University Press.

Sternberg RJ (2005) The theory of successful intelligence. Revista Interamericana de Psicología/Interamerican Journal of Psychology 39(2): 189-202.

Stevenson D (2013) Decision making skill and complex problem solving in team sports. Doctoral Dissertation. Stirling, Scotland: University of Stirling.

Taylor AP (2016) Developing game awareness, perception and decision-making in elite youth footballers. MEd Thesis. Sydney, Australia: The University of Sydney.

Verscheure I, Amans-Passaga C (2014) Pour une éducation de la pensée tactique en volley-ball (For a tactical-thinking education in Volleyball). In J-F Gréhaigne (ed.), L'Intelligence Tactique - Des Perceptions aux Décisions Tactiques en Sports Collectifs, 207-220. Besançon, France: Presses Universitaires de Franche-Comté.

Williams AM, Jackson RC (2019) Anticipation in sport: fifty years on, what have we learned and what research still needs to be undertaken? Psychology of Sport and Exercise 42(May): 16-24.

Yvon F, Zinchenko Y (Eds.) (2011) Vygotsky, une théorie du développement et de l'éducation - Recueil de textes et commentaires (Vygotsky, a theory of development and education - Collection of papers and commentaries). Moscow (Russia): Lomonosov Moscow State University. 